\title{
Hypovitaminosis D, Low Bone Mineral Density, and Diabetes Mellitus as Probable Risk Factors for Benign Paroxysmal Positional Vertigo in the Elderly
}

\author{
Jessica Aparecida Bazoni ${ }^{1}$ Daiane Soares Almeida Ciquinato ${ }^{10}$ Audrey de Souza Marquez ${ }^{1}$ \\ Viviane de Souza Pinho Costa ${ }^{1}$ Glória de Moraes Marchiori ${ }^{2} \quad$ Luciana Lozza de Moraes Marchiori ${ }^{1}$ (1) \\ ${ }^{1}$ Speech therapy Department, Unopar, Londrina, PR, Brazil \\ 2 Departament of Medicine, UniCesumar, Maringá, PR, Brazil \\ Address for correspondence Daiane Soares De Almeida Ciquinato, \\ Master, Av. Paris 675, Londrina, Paraná, Brasil \\ (e-mail: ciquinato19@gmail.com).
} Int Arch Otorhinolaryngol 2020;24(3):e272-e277.

\begin{abstract}
Keywords

- vitamin D

- bone mineral density

- benign paroxysmal positional vertigo

- elderly

Introduction Studies have found that elderly patients with benign paroxysmal positional vertigo (BPPV) may present low levels of vitamin $\mathrm{D}(25(\mathrm{OH}) \mathrm{D})$, changes in bone mineral density, and diabetes mellitus (DM).

Objective: To investigate the possible association between BPPV, bone mineral density, hypovitaminosis $\mathrm{D}, 25(\mathrm{OH}) \mathrm{D}$ and $\mathrm{DM}$.

Methods The sample consisted of 109 elderly subjects. The BPPV was verified by a standardized questionnaire and the Dix-Hallpike maneuver. Blood samples were collected for the investigation of $25(\mathrm{OH}) \mathrm{D}$ serum levels. The bone mineral density was evaluated by means of a densitometer. Diabetes mellitus verification was performed using a self-reported questionnaire.

Results Of the 109 participants, 17 had BPPV. There was a statistically significant difference between BPPV and gender $(p=0.027$, phi $=0.222)$, with female representing $88.2 \%$ of those with BPPV. In the group with BPPV, there was a statistically significant difference for the amount of vitamin $D$ found $(p=0.001)$ and for age $(p=0.001)$. In the elderly group with DM and BPPV, a difference was found for the standard deviation of the femur $(p=0.022)$ with posthoc Dunn, identifying the difference between diabetics with and without BPPV $(p=0.047)$.

Conclusion Although no association was found (25 (OH) D levels) with BPPV in the general population of this study, it was observed that there was an association with bone mineral density in the elderly group with DM and BPPV, and, in the group with BPPV, there was an association between the amount of vitamin $D$ and age.
\end{abstract}

\section{Introduction}

Benign paroxysmal positional vertigo (BPPV) is defined as a vestibular dysfunction of peripheral origin and unilateral predominance, characterized by episodes of vertigo that are usually intense, short in duration, and typically triggered by certain postural changes in the head. ${ }^{1-3}$ Benign paroxysmal positional vertigo represents $\sim 20$ to $30 \%$ of dizziness diag-

received

May 4, 2019

accepted

September 12, 2019

published online

December 13, 2019 noses in specialized clinics, with an incidence of $0.6 \%$ per year, and its prevalence rate increases to $3.4 \%$ in individuals over 60.2 years of age. It is the most common cause of vertigo in adults, affecting women twice as much and constituting in most cases of the idiopathic BPPV. ${ }^{4-6}$

Low levels of vitamin $D$ have been associated with the development and recurrence of BPPV, with a possible level of disturbance attributed to vestibular endolymph $\mathrm{Ca}^{2+}$, which

Copyright @ 2020 by Thieme Revinter

Publicações Ltda, Rio de Janeiro, Brazil

License terms

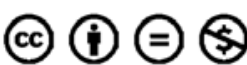


results in the formation of abnormal otoconia. Calcium is the main component of these otoconia that are generated by the same mechanism of calcium absorption that occurs in bones, which, in turn, has many important biological functions, including the regulation of homeostasis of calcium. ${ }^{7-9}$

All people have several free otoconia in the semicircular canals; however, the body is able to absorb calcium usually within hours or days without triggering symptoms. ${ }^{9}$ Epidemiological studies have found that a significant portion of the world population, regardless of age, ethnicity, and geographic location, has a prevalence of osteoporosis and low serum vitamin D levels in patients with BPPV. ${ }^{8,10-13}$ Bone mineral density (BMD) and serum 25-hydroxyvitamin D (25 (OH) D) levels may be affected by several factors, such as age; gender; preexisting metabolic disorders, such as diabetes mellitus (DM), and lifestyle. ${ }^{14,15}$

Since there is a scarcity of studies that provide evidence of such associations, which may lead to better prevention and treatment options for BPPV in the elderly, this research aimed to investigate a possible association between BPPV, bone mineral density, hypovitaminosis D, levels of $25(\mathrm{OH}) \mathrm{D}$, and DM in this population.

\section{Methods}

\section{Study Design}

The present study is a cross-sectional analysis. The sample consisted of a population of 43,610 elderly enrolled in the 38 Basic Health Units of the urban area of the municipality of Londrina, Parana, Brazil. The sample selection of individuals was randomly stratified, taking into consideration the five regions of the city; They are $15 \%$ of the central region, $27 \%$ of the northern region, $23 \%$ in the southern region, $19 \%$ in the eastern region, and $16 \%$ in the western region. This study is part of the ELLO Project (Study on Aging and Longevity).

Part of this sample was selected to perform the bone densitometry test. The selection criteria for bone densitometry were: to be physically independent according to the functional classification proposed by Spirduso: 3 (physically independent) and 4 (physically active). ${ }^{16}$ Of the 323 elderly individuals who were invited to perform bone densitometry, 42 were not found, 28 refused to participate, 135 were excluded because they had one of more of the exclusion criteria, and 9 died. The final sample consisted of 109 elderly subjects. For this part of the study, the following inclusion criteria were used: age $\geq 60$ years; both genders; voluntarily agree to participate in the study. The exclusion criteria were: present unilateral and/or bilateral conductive or mixed hearing loss; present otorrhea, surgery in the vestibular system, and not agreeing to perform one of the study evaluations. The study was approved by the ethics committee of the institution, and all subjects participated voluntarily after signing the free and informed consent term to comply with resolution $466 / 12 .^{17}$

\section{Clinical Evaluation}

Benign paroxysmal positional vertigo diagnosis was verified by vertigo complaint, an audiological anamnesis, ${ }^{18}$ and the Dix-Hallpike diagnostic maneuver. ${ }^{19}$ The diagnosis of BPPV includes a greater caution regarding the history of dizziness associated with changes in head position, confirmed by the Dix-Hallpike maneuver, and the patient who presented nystagmus was considered with BPPV.

The 25-OH-vitamin D dosages were performed in serum samples by fully automated chemiluminescent method (Architect iSR2000-Abbott). They were adopted according to 25-OH vitamin D serum with the following criteria: Vitamin D deficiency was defined as a 25(OH)D below $20 \mathrm{ng} / \mathrm{ml}$ (50 nmol/liter), vitamin insufficiency $D$ as a $25(\mathrm{OH}) \mathrm{D}$ of 21 to $29 \mathrm{ng} / \mathrm{ml}$, normal or sufficient as a $25(\mathrm{OH}) \mathrm{D} \geq 30 \mathrm{ng} / \mathrm{ml}$ and hypovitaminosis $\mathrm{D}$ as a $25(\mathrm{OH}) \mathrm{D} \leq 29 \mathrm{ng} / \mathrm{ml}^{20,21}$

The BMD was evaluated with the QDR 4500 duo-energy densitometer (Hologic Inc., Bedford, MA, USA) in the lumbar spine (L1-L4), femoral neck and total femur regions. For the analysis, we used the criteria of the World Health Organization, ${ }^{22}$ normal BMD with T-score up to $-1.0 \pm$ standard deviation (SD), osteopenia with T-score between -1.0 to $-2.4 \pm \mathrm{SD}$, and osteoporosis with T-score $\leq-2.5 \pm \mathrm{SD}$ at any bone site.

Specific data on vertigo complaint and comorbidities ${ }^{23}$ were also verified with self-reported responses.

The Statistical Package of Social Science (SPSS) 20.0 for Windows (SPSS Inc., Chicago, IL, USA) was used for the statistical analysis. The normality of the data was verified with the Kolmogorov-Smirnov test, but as the assumption was not met, the Mann-Whitney and Kruskal-Wallis test with Dunn posthoc were selected to analyze the quantitative variables in the comparison between the groups. For analysis of subgroups, normality was also verified. The $t$-test for a sample selected for the BPPV subgroup. The KolmogorovSmirnov test for a sample was selected for the control group. The Chi-square test was selected to verify the association between BPPV and other categorical variables. A 95\% confidence interval and a significance level of $5 \%(p<0.05)$ were established for all tests.

\section{Results}

The variables analyzed were: serum levels of vitamin D, vitamin D classification (deficiency, insufficiency, normal), hypovitaminosis, BMD, diabetes (DM). In addition to the covariates related to personal data (sex and age), symptoms (tinnitus and headache), lifestyle (physical activity), and comorbidity (hypertension and diabetes mellitus). Of the 109 participants, 17 had BPPV confirmed by the DixHallpike maneuver. The general characteristics of the sample are presented in -Table 1. (view - Table 1).

There was a significant association between BPPV and gender $(p=0.027$; $p h i=0.222)$, as shown in - Table 2 . The female gender represented $88.2 \%$ of those with BPPV. There was also an association between hypovitaminosis and gen$\operatorname{der}(p=0.038$; phi $=0.199)$; of the female group, $68.7 \%$ were classified as hypovitaminosis D.

Although no statistical difference was found between BPPV and bone mineral density $(p=0.125)$, lumbar spine densitometry was the variable that most approached a significant value. Only $23.5 \%$ of the elderly with BPPV diagnosed with normal densitometry, $47.1 \%$ with osteopenia, 
Table 1 Descriptive data of the sample $(N=109)$

\begin{tabular}{|l|l|}
\hline GENERAL CHARACTERISTICS & $\mathrm{N}(\%)$ \\
\hline GROUPS & \\
\hline With BPPV & $\mathrm{N}=17(15.6 \%)$ \\
\hline Without BPPV & $\mathrm{N}=92(84.4 \%)$ \\
\hline GENDER & \\
\hline Female & $\mathrm{N}=69(63.3 \%)$ \\
\hline Male & $\mathrm{N}=40(36.7 \%)$ \\
\hline AGE RANGE & \\
\hline $60-64$ years & $\mathrm{N}=32(29.4 \%)$ \\
\hline $65-74$ years & $\mathrm{N}=58(53.2 \%)$ \\
\hline 75 years and over & $\mathrm{N}=19(17.4 \%)$ \\
\hline Mean \pm standard deviation & $68.7 \pm 6.1^{\mathrm{a}}$ \\
\hline VITAMIN D & $25.5 \pm 8.7^{\mathrm{a}}$ \\
\hline Normal $(\geq 30 \mathrm{ng} / \mathrm{ml})$ & $\mathrm{N}=26(23.9 \%)$ \\
\hline Insufficiency $(21-29 \mathrm{ng} / \mathrm{ml})$ & $\mathrm{N}=49(45.0 \%)$ \\
\hline Deficiency $(\leq 29 \mathrm{ng} / \mathrm{ml})$ & $\mathrm{N}=34(31.2 \%)$ \\
\hline HYPOVITAMINOSIS D & \\
\hline Normal $(\geq 30 \mathrm{ng} / \mathrm{ml})$ & $\mathrm{N}=26(23.9 \%)$ \\
\hline Hypovitaminosis D $(\leq 29 \mathrm{ng} / \mathrm{ml})$ & $\mathrm{N}=83(71.6 \%)$ \\
\hline BMD & \\
\hline Normal & $\mathrm{N}=21(19.3 \%)$ \\
\hline Osteopenia & $\mathrm{N}=56(51.4 \%)$ \\
\hline Osteoporosis & $\mathrm{N}=32(29.4 \%)$ \\
\hline
\end{tabular}

Abbreviations: BMD, bone mineral density; BPPV, benign paroxysmal positional vertigo.

${ }^{a}$ (mean and standard deviation).

and $29.4 \%$ with osteoporosis. That is, the elderly with BPPV presented worse results than their healthy controls.

Subgroup analysis showed that, in the group with BPPV, there was a statistically significant difference for the amount of vitamin $\mathrm{D}$ found $(p=0.001)$ and for age $(p=0.001)$ when compared with its healthy controls, as shown in - Table 3. Adjusted analyzes for BPPV and comorbidities, such as arterial hypertension and DM, were also performed. The KruskalWallis test identified a difference for the elderly group with DM and BPPV for the femur SD $(p=0.022)$ with Dunn posthoc identifying the difference between the groups with BPPV and with DM, and the group without BPPV and with DM $(p=0.047)$. The other analyzed variables presented $p>0.05$.

\section{Discussion}

In this study, no association was found between low levels of BMD, hypovitaminosis D and levels of $25(\mathrm{OH}) \mathrm{D}$ and DM with BPPV in the general population. However, it was observed that in the elderly group with DM and BPPV, a statistically significant difference was found for BMD with the SD of the femur. In the group with BPPV, there was a statistically significant difference for the variables amount of $25(\mathrm{OH})$ $\mathrm{D}$ found and age. These findings contribute to group information on this controversial aspect of human health.

The effect of low levels of BMD, hypovitaminosis D and levels of $25(\mathrm{OH}) \mathrm{D}$, and DM on the health of the older population has been largely studied; however, their effects on BPPV is less known. Previous studies have found an association between changes in BPPV hypovitaminosis D. ${ }^{8,24}$

Regarding the prospective relation between low levels of BMD, hypovitaminosis D and levels of $25(\mathrm{OH}) \mathrm{D}$, and DM with BPPV, other studies diverge on the associations found.

For instance, in a study to investigate the relationship between BMD and 25-hydroxyvitamin D with the occurrence and recurrence of BPPV, evaluted the records of 130 idiopathic BPPV. The records of 130 idiopathic BPPV patients ( $55 \pm 12$ years old, 30 men and 100 women) and 130 age- and gendermatched controls who underwent bone mineral densitometry. Was compared the BMD and serum 25-hydroxyvitamin D between the patients and controls, and also compared the BMD between recurrent and non-recurrent BPPV groups. Among the female subjects, the BPPV group showed significantly decreased BMD compared with the controls $(p<0.05)$. The men in the control group had significantly higher 25-hydroxyvitamin D levels than the men with BPPV $(p<0.05)$. Sixty-three patients $(48 \%)$ reported recurrent attacks of BPPV. The women with recurrent BPPV were significantly older and showed a significantly lower BMD than non-recurrent women $(p<0.001)$. However, multiple regression analysis revealed that age alone was significantly associated with the recurrence of BPPV in women. Bone mineral density in women and serum 25-hydroxyvitamin $D$ levels in men are associated with the occurrence of BPPV. Only age is an independent predictor of recurrence, although a low BMD and age correlate with the recurrence of BPPV. ${ }^{25}$ Similar findings regarding gender and age were observed in our study, since there was a statistically significant difference in the amount of vitamin $\mathrm{D}$, age, and gender in the BPPV group.

We also found that in the elderly group with DM and BPPV, there was a significant difference in relation to BMD for femoral SD, although we found no association between BMD and $25(\mathrm{OH}) \mathrm{D}$ levels in women; this association only occurred in BPPV in the total population. The exact pathophysiology of diabetic damage to the peripheral vestibular organ is not yet fully understood. However, a loss of sacculate type I hair cells has been described in human subjects with DM. ${ }^{26,27}$ Glucose uptake is regulated in most tissues by the expression of glucose transporters on cell surfaces. ${ }^{28}$ In DM, the saccule represents the main structure of the maze affected by pathological damage due to endolymphatic hydrops. Cohen et $\mathrm{al}^{29}$ analyzed a cohort of 112 patients with BPPV, of whom 24 (14\%) had DM. The authors pointed out that this prevalence is higher than the $4 \%$ rate of diabetics in the United States population. A recent literature review suggests that a large number of peripheral vestibular changes such as BPPV and DM may be strongly influenced by blood insulin and blood glucose levels. ${ }^{30}$

Recently a meta-analysis did not support the lower vitamin D level relationship with BPPV occurrence. However, it 
Table 2 Comparative analyses between groups $(n=109)$

\begin{tabular}{|c|c|c|c|c|}
\hline & & BPPV & Controls (without BPPV) & $\begin{array}{l}P \\
\text { (Mann-Whitney test) }\end{array}$ \\
\hline \multicolumn{5}{|l|}{ Quantitative Variables } \\
\hline Age (years) & & $67[10]^{b}$ & $68[7.75]$ & $\begin{array}{l}p=0.728 \\
U=823.500\end{array}$ \\
\hline Vitamin D (ng/ml) & & $27.8[10.10]$ & $23.8[11.28]$ & $\begin{array}{l}p=0.260 \\
U=917.000\end{array}$ \\
\hline Categorical variables & & & & $\begin{array}{l}P \\
\text { (Chi-square test) }\end{array}$ \\
\hline \multirow[t]{2}{*}{ Sex } & Female & $15(88.2 \%)$ & $54(58.7 \%)$ & \multirow{2}{*}{$\begin{array}{l}p=0.020^{*} \\
X^{2}=5.390\end{array}$} \\
\hline & Male & $2(11.8 \%)$ & $38(41.3 \%)$ & \\
\hline \multirow[t]{2}{*}{ Physical activity } & No-active & $10(17.9 \%)$ & $46(82.1 \%)$ & \multirow{2}{*}{$\begin{array}{l}p=0.504 \\
X^{2}=0.447\end{array}$} \\
\hline & Active & $7(13.2 \%)$ & $46(86.8 \%)$ & \\
\hline \multirow[t]{3}{*}{ Vitamin D classification } & Normal & $6(35.3 \%)$ & 20 (21.7\%) & \multirow{3}{*}{$\begin{array}{l}p=0.304 \\
X^{2}=2.317\end{array}$} \\
\hline & Insufficiency & $8(47.1 \%)$ & $41(44.6 \%)$ & \\
\hline & Deficiency & $3(17.6 \%)$ & $31(33.7 \%)$ & \\
\hline \multirow[t]{2}{*}{ D hypovitaminosis } & Normal & $6(35.3 \%)$ & $20(21.7 \%)$ & \multirow{2}{*}{$\begin{array}{l}p=0.371 \\
X^{2}=0.801\end{array}$} \\
\hline & Hypovitaminosis & $11(64.7 \%)$ & $72(78.3 \%)$ & \\
\hline \multirow[t]{3}{*}{ Spine BMD } & Normal & $4(23.5 \%)$ & $45(48.9 \%)$ & \multirow{3}{*}{$\begin{array}{l}p=0.125 \\
X^{2}=4.019\end{array}$} \\
\hline & Insufficiency & $8(47.1 \%)$ & 30 (32.6\%) & \\
\hline & Deficiency & $5(29.4 \%)$ & 17 (18.5\%) & \\
\hline \multirow[t]{2}{*}{ Tinnitus } & Yes & $9(52.9 \%)$ & $35(38 \%)$ & \multirow{2}{*}{$\begin{array}{l}p=0.250 \\
X^{2}=1.323\end{array}$} \\
\hline & No & $8(47.1 \%)$ & $57(62 \%)$ & \\
\hline \multirow[t]{2}{*}{ Hypertension } & Yes & $12(70.6 \%)$ & $52(56.5 \%)$ & \multirow{2}{*}{$\begin{array}{l}p=0.279 \\
X^{2}=1.171\end{array}$} \\
\hline & No & $5(29.4 \%)$ & $40(43.5 \%)$ & \\
\hline \multirow[t]{2}{*}{ DM } & Yes & $5(29.4 \%)$ & $20(21.7 \%)$ & \multirow{2}{*}{$\begin{array}{l}p=0.706 \\
X^{2}=0.142\end{array}$} \\
\hline & No & $12(70.6 \%)$ & $72(78.3 \%)$ & \\
\hline \multirow[t]{2}{*}{ Headache } & Yes & 9 (52.9\%) & 28 (30.4\%) & \multirow{2}{*}{$\begin{array}{l}p=0.072 \\
X^{2}=3.241\end{array}$} \\
\hline & No & $8(47.1 \%)$ & 64 (69.6\%) & \\
\hline
\end{tabular}

Abbreviations: BMD, bone mineral density; BPPV, benign paroxysmal positional vertigo; DM, diabetes mellitus.

${ }^{\mathrm{b}}$ Median and interquartile range

*Statistically significant difference.

Table 3 Comparative analyses subgroups

\begin{tabular}{|l|l|l|l|l|}
\hline & $\begin{array}{l}\text { BPPV } \\
\text { (cases) } \\
\mathbf{N}=17\end{array}$ & $\begin{array}{l}P \\
\text { (BPPV group) }\end{array}$ & $\begin{array}{l}\text { Without BPPV (controls) } \\
\mathbf{N}=92\end{array}$ & $\begin{array}{l}P \\
\text { (control group) }\end{array}$ \\
\hline Variables & & & & \\
\hline Vitamin D (ng/ml) & $27.8[10.1]$ & $p=0.001^{*}$ & $23.8[11.28]$ & $p=0.704$ \\
\hline Age (years) & $67.0[10.0]$ & $p=0.001^{*}$ & $68[7.75]$ & $p=0.273$ \\
\hline
\end{tabular}

Abbreviation: BPPV, benign paroxysmal positional vertigo.

*Statistically significant difference.

supports, with normal heterogeneity, the fact that recurrent episodes of BPPV are associated with low vitamin D. ${ }^{30}$

Although in our study we found a significant difference within the subgroup, in the BPPV-adjusted analysis with a higher amount of vitamin $\mathrm{D}$ in its group, we did not find this difference in the general study population, constituting serum $25(\mathrm{OH}) \mathrm{D}$ levels in the BPPV group (27.8 ng/ml) and in the control group decreased serum levels ( $23.8 \mathrm{ng} / \mathrm{ml})$. One explanation for the non-association found between low BMD levels, hypovitaminosis D, $25(\mathrm{OH}) \mathrm{D}$ levels, and DM in relation to BPPV in the general population may be related to the fact that the serum $25(\mathrm{OH})$ D level in the population was not sufficiently low in our study as compared with the study by Talaat et al, ${ }^{10}$ which indicates that the vitamin $\mathrm{D}$ concentration in the 
control group (19.5 $\mathrm{ng} / \mathrm{ml}$ ) is higher than in the BPPV group $(16.0 \mathrm{ng} / \mathrm{ml})$. Another explanation concerns latitude differences involving hours of sun exposure. This could explain the variation in serum levels in different studies, ${ }^{20,21,31,32}$ since vitamin $\mathrm{D}$ is acquired in humans through the production of 7 dehydrocholesterol, provitamin D3 in the skin, absorption of UVB radiation and ingestion. ${ }^{31,33-37}$

Mean serum vitamin D concentrations may differ between institutions in the study country. ${ }^{8,10,38,39}$ Therefore, direct comparison of values in the study results requires close attention. These differences in serum levels may be one of the factors for the divergence of research findings regarding the relationship between vitamin D and BPPV.

The strengths of the present study include the bone densitometry test, the application of Dix-Hallpike diagnostic maneuver, and the $25(\mathrm{OH}) \mathrm{D}$ dosages. The limitations include the of self-reported vertigo complaint. However, the use of self-reported measures of vertigo complaint is habitual in prospective studies due to its simplicity and lowcosts. ${ }^{40}$ In addition, the vertigo complaint was supported by the application of Dix-Hallpike maneuver.

From the specific literature and the results of the present research, it is shown the need to verify the comorbidities involved in the BPPV for good targeting of the better treatment selection.

\section{Conclusion}

Although there was no association between low levels of BMD, hypovitaminosis D, and levels of vitamin D $(25(\mathrm{OH}) \mathrm{D}$ with BPPV in the general population of this study, in the elderly group with DM and BPPV, it was found significant difference for SD of the femur, and, in the group with BPPV, there was a statistically significant difference for the amount of vitamin D found and for the age.

\section{Financial Assistance}

Fundação Nacional de Desenvolvimento de Ensino Superior Particular (FUNADESP).

\section{Conflicts of Interest}

The authors have no conflicts of interest to declare.

\section{References}

1 von Brevern M, Bertholon P, Brandt T, et al. Benign paroxysmal positional vertigo: Diagnostic criteria. J Vestib Res 2015;25(34):105-117

2 Burlamaqui JC, Campos CAH, Mesquita Neto O. Manobra de Epley para Vertigem Postural Paroxistica Benigna: revisão sistemática. Acta Otorrinolaringol. 2006;24:38-45

3 Dix MR, Hallpike CS. The pathology, symptomatology and diagnosis of certain common disorders of the vestibular system. Ann Otol Rhinol Laryngol 1952;61(04):987-1016

4 von Brevern M, Radtke A, Lezius F, et al. Epidemiology of benign paroxysmal positional vertigo: a population based study. J Neurol Neurosurg Psychiatry 2007;78(07):710-715

5 Silva C, Amorim AM, Paiva A. Benign paroxysmal positional vertigo-a review of 101 cases. Acta Otorrinolaringol Esp 2015; 66(04):205-209
6 Cho EI, White JA. Positional vertigo: as occurs across all age groups. Otolaryngol Clin North Am 2011;44(02):347-360, viii

7 Marom T, Oron Y, Watad W, Levy D, Roth Y. Revisiting benign paroxysmal positional vertigo pathophysiology. Am J Otolaryngol 2009;30(04):250-255

8 Jeong SH, Kim JS, Shin JW, et al. Decreased serum vitamin D in idiopathic benign paroxysmal positional vertigo. J Neurol 2013; 260(03):832-838

9 Gans R. Benign paroxysmal positional vertigo: a common dizziness sensation. Audiology online serial on the internet. 2002. Disponivel em: URL: http://www.audiologyonline.com/articles/ article_detail.asp?article_id=86. Acesso em 14 junho 2018.

10 Talaat HS, Abuhadied G, Talaat AS, Abdelaal MS. Low bone mineral density and vitamin $\mathrm{D}$ deficiency in patients with benign positional paroxysmal vertigo. Eur Arch Otorhinolaryngol 2015;272 (09):2249-2253

11 Mikulec AA, Kowalczyk KA, Pfitzinger ME, Harris DA, Jackson LE. Negative association between treated osteoporosis and benign paroxysmal positional vertigo in women. J Laryngol Otol 2010; 124(04):374-376

12 Yu S, Liu F, Cheng Z, Wang Q; K Yu S. Association between osteoporosis and benign paroxysmal positional vertigo: a systematic review. BMC Neurol 2014;14:110

13 Parham K, Leonard G, Feinn RS, Lafreniere D, Kenny AM. Prospective clinical investigation of the relationship between idiopathic benign paroxysmal positional vertigo and bone turnover: a pilot study. Laryngoscope 2013;123(11):2834-2839

14 Tuzun S, Eskiyurt N, Akarirmak U, et al; Turkish Osteoporosis Society. The impact of a FRAX-based intervention threshold in Turkey: the FRAX-TURK study. Arch Osteoporos 2012;7:229-235

15 Lee JH, O'Keefe JH, Bell D, Hensrud DD, Holick MF. Vitamin D deficiency an important, common, and easily treatable cardiovascular risk factor? J Am Coll Cardiol 2008;52(24):1949-1956

16 Spirdurso WW. Dimensoes Fisicas do Envelhecimento. Barueri, Manole2005

17 Brasil (2012). Resolução 466, de 12 de dezembro de 2012. In Uniao DOd (ed).

18 Miller MH. A integração dos achados audiológicos. In: Katz J (Org). Tratado de audiologia clínica. São Paulo: Manole; 1999; 3:268-70

19 Bhattacharyya N, Baugh RF, Orvidas L, et al; American Academy of Otolaryngology-Head and Neck Surgery Foundation. Clinical practice guideline: benign paroxysmal positional vertigo. Otolaryngol Head Neck Surg 2008;139(05, Suppl 4):S47-S81

20 Holick MF, Binkley NC, Bischoff-Ferrari HA, et al; Endocrine Society. Evaluation, treatment, and prevention of vitamin D deficiency: an Endocrine Society clinical practice guideline. J Clin Endocrinol Metab 2011;96(07):1911-1930

21 Souberbielle JC, Body JJ, Lappe JM, et al. Vitamin D and musculoskeletal health, cardiovascular disease, autoimmunity and cancer: Recommendations for clinical practice. Autoimmun Rev 2010;9 (11):709-715

22 OMS. World Health Report. Suica: WHO; 2010

23 Lapenna R, Faralli M, Del Zompo MR, Cipriani L, Mobaraki PD, Ricci G. Reliability of an anamnestic questionnaire for the diagnosis of benign paroxysmal positional vertigo in the elderly. Aging Clin Exp Res 2016;28(05):881-888

24 Ding J, Liu L, Kong WK, Chen XB, Liu X. Serum levels of 25-hydroxy vitamin $D$ correlate with idiopathic benign paroxysmal positional vertigo. Biosci Rep 2019;39(04):BSR20190142

25 Yang CJ, Kim Y, Lee HS, Park HJ. Bone mineral density and serum 25-hydroxyvitamin $\mathrm{D}$ in patients with idiopathic benign paroxysmal positional vertigo. J Vestib Res 2018;27(5-6):287-294

26 Kocdor P, Kaya S, Erdil M, Cureoglu S, Paparella MM, Adams ME. Vascular and neuroepithelial histopathology of the saccule in humans with diabetes mellitus. Otol Neurotol 2016;37(05):553-557

27 Degerman E, Rauch U, Lindberg S, Caye-Thomasen P, Hultgårdh A, Magnusson M. Expression of insulin signalling components in the 
sensory epithelium of the human saccule. Cell Tissue Res 2013; 352(03):469-478

28 Thorens B, Mueckler M. Glucose transporters in the 21st Century. Am J Physiol Endocrinol Metab 2010;298(02):E141-E145

29 Cohen HS, Kimball KT, Stewart MG. Benign paroxysmal positional vertigo and comorbid conditions. ORL J Otorhinolaryngol Relat Spec 2004;66(01):11-15

30 Gioacchini FM, Albera R, Re M, Scarpa A, Cassandro C, Cassandro E. Hyperglycemia and diabetes mellitus are related to vestibular organs dysfunction: truth or suggestion? A literature review. Acta Diabetol 2018;55(12):1201-1207

31 Holick MF. Vitamin D deficiency. N Engl J Med 2007;357(03): 266-281

32 McGrath JJ, Féron FP, Burne TH, Mackay-Sim A, Eyles DW. Vitamin D3-implications for brain development. J Steroid Biochem Mol Biol 200489-90(1-5):557-560

33 Lanteri P, Lombardi G, Colombini A, Banfi G. Vitamin D in exercise: physiologic and analytical concerns. Clin Chim Acta 2013; 415:45-53

34 Grant WB. Benefits of ultraviolet-B irradiance and vitamin D in youth. J Steroid Biochem Mol Biol 2013;136:221-223
35 Scott D, Ebeling PR, Sanders KM, Aitken D, Winzenberg T, Jones G. Vitamin $\mathrm{d}$ and physical activity status: associations with five-year changes in body composition and muscle function in communitydwelling older adults. J Clin Endocrinol Metab 2015;100(02):670-678

36 Bell NH, Godsen RN, Henry DP, Shary J, Epstein S. The effects of muscle-building exercise on vitamin D and mineral metabolism. J Bone Miner Res 1988;3(04):369-373

37 Karataş A, Acar Yüceant G, Yüce T, Hacı C, Cebi IT, Salviz M. Association of benign paroxysmal positional vertigo with osteoporosis and vitamin D deficiency: a case-controlled study. J Int Adv Otol 2017;13(02):259-265

38 AlGarni MA, Mirza AA, Althobaiti AA, Al-Nemari HH, Bakhsh LS. Association of benign paroxysmal positional vertigo with vitamin D deficiency: a systematic review and meta-analysis. Eur Arch Otorhinolaryngol 2018;275(11):2705-2711

39 Buki B, Ecker M, Junger H, Lundberg YW. Deficiência de vitamina D e vertigem posicional paroxística benigna. Eur Arch Otorhinolaryngol 2013;80:201-204

40 Bazoni JA, Mendes WS, Moreira MD, et al. Queixa de vertigem e prática de atividade física regular em idosos. Rev CEFAC 2013; 15:1447-1452 